\title{
PHILOSOPHY, LITERATURE, AND EVERYDAY LIFE IN THE SECOND SEX: THE CURRENT BEAUVOIR REVIVAL
}

In her interviews with Sartre, published posthumously in $L a$ Cérémonie des Adieux (Adieux: A Farewell to Sartre), Simone de Beauvoir largely seems to share Sartre's belief that philosophy is one thing, literature another. In these conversations of 1974, Sartre enumerates some of the differences: for example, philosophy, he claims, can be written with ease, even under the influence of drugs-he himself had consumed great quantities of Corydrane while composing his mammoth Critique of Dialectical Reason; good literature, on the other hand, usually requires a series of drafts. ${ }^{1}$ Both Sartre and Beauvoir appear to accept here a conventional distinction that is based on an essentialist conception of genres of writing, but it is one which in practice they continually put in question. My first aim in this essay is to challenge the distinction itself, at least in the rigid form in which Sartre and Beauvoir understand it. My second aim is to explore the basis of Beauvoir's position in light of what she says about philosophy in her important autobiographical The Prime of Life. My third and final aim is to discuss the current Beauvoir revival, or rather first awakening of interest in Beauvoir as a philosopher that is reflected in numerous recent books, articles, conferences, and symposia and largely centers on The Second Sex.

\section{The Philosophy-Literature Dichotomy}

In accepting the conventional philosophy-literature dichotomy, Sartre and Beauvoir were insufficiently reflective. I will offer some narrative rather than formal arguments to support this claim. But first let me insist on what I am not arguing. I do not dispute the possibility of rating quality of style. Sartre's Critique of Dialectical Reason, for example, contains passages that are abominable from a stylistic point of view, and, as indicated above, Sartre offers one excuse for this. Good style, I would like to think, enhances rather than undermines solid philosophical thinking, especially if one allows it to take a plurality of

1. Simone de Beauvoir, Adieux: A Farewell to Sartre, trans. P. O'Brian (New York: Pantheon, 1984)174. 
forms. ${ }^{2}$ The Second Sex in particular illustrates my point. It is indeed a work of considerable philosophical significance but it is also written in a very pleasing French, especially the second half, Book 2, 'L' Expérience Vécue" according to the French original- "Woman's Life Today" as the justly maligned English translation calls it. It consists of descriptions - philosophically ordered descriptions, as I shall insist - of ordinary life as women experience it at different stages and/or in different occupations.

On both sides of the Atlantic there has recently appeared a spate of literature-_"philosophical literature" in common English parlance-that addresses the role of narrative in philosophy. ${ }^{3}$ Against Aristotle's famous assertion of the ancient quarrel (ancient in his own time, of course) between philosophy and history, many of our contemporaries seem to claim that philosophy is nothing but a sort of conscious or unconscious history. Even among Anglo-American analytic philosophers it has become commonplace to use the expression "to tell a story" when characterizing one or another philosophical theory. Simultaneously, the sub-field philosophy-in-literature (identified with the work of Martha Nussbaum, among others) has achieved considerable recognition in the United States. And in contrast to only a few decades ago, fewer philosophers consider it terrible form any more to weave autobiographical remarks into essays purporting to deal with philosophical topics. After all, the so-called "father of modern philosophy," René Descartes himself, did so on a grand scale in his Discours de la Méthode!

In this context, I have a narrative of my own to offer. My first year after college and during the heyday of Sartrean-Beauvoirean existentialism, I attended philosophy courses in Lille. Jean Grenier, Camus' former teacher and friend, asked me to do a class report on Wittgenstein's Tractatus Logico-Philosophicus, a copy of which had

2. Brand Blanshard, one of my former teachers, wrote a short essay On Philosophical Style (Manchester (UK): Manchester University Press, 1954).

3. See for example David Carr's Time, Narrative, and History (Bloomington: Indiana University Press, 1986). Carr is strongly indebted to Edmund Husserl's The Crisis of European Sciences and Transcendental Phenomenology. 
just been acquired by the department's library. After the session, a French graduate student came up to me to thank me for my presentation, but French philosophy students, he added, had too much of a literary bent to be comfortable with that kind of material. In retrospect, I see the double or triple irony of this moment. First there are the Bachelards, father and daughter. Suzanne Bachelard, the French translator of Husserl's early, more logic-oriented work, was also teaching one of my courses. Some years ago I learned from Geneviève Sevel that the two of them had been students of Simone de Beauvoir's in 1942-43 during Beauvoir's last year of lycée teaching. Suzanne Bachelard tended to be extremely formalistic and non-literary in her approach to her subject, the philosophy of logic_-during the very years when her father, Gaston Bachelard, greatly influenced the AngloAmerican literary theory movement known as The New Criticism! Second and conversely, we now know that Wittgenstein's own cultural formation, Weltanschauung, and form of life-more bizarre and unconventional in certain respects than pure fiction-shaped his philosophical writings, particularly the Tractatus, in ways of which most of us were unaware. In short, the philosophy/literature/life interrelationships were stronger and more complex than any of us really understood... But I digress: after all, this is supposed to be an essay in philosophy, not a "mere" narrative.

I trust that my basic point is clear. In the portion of their dialogue to which I have alluded, Sartre and Beauvoir were affected by a prejudice that has been part of the socialization of philosophy students almost everywhere up to the present, even if it is being enforced less rigorously now: philosophy is one thing, literature another, and life, to which both genres refer in different ways, yet a third. Philosophy, so this story goes, is further removed from life than literature, yet good philosophy is also closer to life because like life it is real and true. ${ }^{4}$ Literature, however, i.e. most prose literature (which to some extent includes history and biography, which are inevitably distortive), remains at the level of fiction. This preconception influenced Sartre even though he always insisted on being concrete in philosophy, deftly used phenomenological descriptions to support broad philosophical generalizations in even his earliest works, and finally discovered $l e$ vécu-a discovery which he himself acknowledged to have occurred

4. In this context, one should recall the title of Sartre's posthumouslypublished short work of the late 1940s, Vérité et Existence. 
some time after the publication of Being and Nothingness, and which many Beauvoir scholars, now reinforced by Margaret Simons' research on some of Beauvoir's early diaries, have tended to attribute primarily to the latter's influence. ${ }^{5}$ Verbally Beauvoir subscribed to the same preconception. She even defended it explicitly. At the same time, her short 1946 essay "Littérature et Métaphysique" strongly endorsed the idea of the existentialist novel with philosophical import. ${ }^{6}$ I would like to claim, however, that The Second Sex and other Beauvoirean works that abound with similarly broad philosophical generalizations are less subject to this prejudice than Sartre's.

Of course, much more would need to be said in order to generate a comprehensive theory of the relationships among philosophy, literature, and life out of the writings of our heroine and hero. Above all, there is the issue of transcendence in all of its many meanings, only some of which are captured by Sartre's and Beauvoir's usages of the term-usages which themselves differ significantly between the two of them. That is, great philosophy in some manner always transcends the level of daily life, and "transcendence" always carries a connotation of the ecstatic and timeless, even when employed by unequivocally non-religious writers such as Beauvoir and Sartre. But, I would maintain, so does great prose fiction such as the work of Dostoevsky.

\section{Beauvoir's Understanding of Philosophies as Systems}

In "Simone de Beauvoir Writing the Self," Jo-Ann Pilardi cites a passage from La Force de l' Âge (The Prime of Life) that strikes me as very important. Beauvoir explains there why she decided to pursue a literary career in which she could exhibit her originality rather than

5. Sartre acknowledges this in the interview "The Itinerary of a Thought," which was originally published in New Left Review in 1969. See Jean-Paul Sartre: Between Existentialism and Marxism, trans. J. Mathews (New York: William Morrow and Company, 1974) 41-42. See also my discussion of this in "Sartre and Lived Experience," Research in Phenomenology XI (1981): 75-89. The reference to the notion of lived experience in Beauvoir's 1927 diaries can be found in Margaret A. Simons, Beauvoir and The Second Sex (Lanham: Rowman \& Littlefield, 1999) 205.

6. See Les Temps Modernes I, 7 (avril 1946): 1153-1163. 
attempt to be a philosopher, and she offers us insight into what she understands by this term. These reflections of 1960 are essentially consistent with what she told Margaret Simons and Jessica Benjamin in a 1979 interview, published in Simons' recent volume of essays. Simons, much of whose career has been devoted to establishing Beauvoir's credentials as a philosopher in the face of the latter's obstinate refusal to admit them, pressed her once again on that occasion and extracted from her the opinion that each century produces perhaps two great philosophers, people such as Descartes, Hegel and, in her estimation, Sartre. The two Americans suggested that in the United States "philosophy" has a rather different, broader meaning, even if it is considered difficult by the typical reader, and Beauvoir at least conceded that her own sense of the word was "slightly elevated.",

Thanks to Pilardi's reference I returned to La Force de l' Âge with heightened interest. As it happens, I was studying it on a day on which a student in my existentialism class reported on Robert Denoon Cumming's Phenomenology and Deconstruction. In this book, Cumming raises questions about the very nature of philosophy and especially "schools" of philosophy. Partly because Sartre first learned of Husserl's philosophy through Emmanuel Lévinas' misleading Doctoral dissertation, according to Cumming, Sartre never really understood phenomenology. Although grossly exaggerated, Cumming's claim echoes the passage in The Prime of Life where Beauvoir reports Sartre always to have said that she understood other thinkers, Husserl in particular, more quickly and more accurately than he, an assessment with which she agrees. It is precisely for this reason, she continues, that she never felt capable of being original as a philosopher in the special, elevated sense of system-builder. Then she continues with the words Pilardi cites:

It would be more useful to explain how certain individuals are capable of getting results from that conscious venture into lunacy known as a 'philosophical system,' from which they derive that obsessional attitude which endows their tentative patterns with universal insight and applicability. As I have remarked before, women are not by nature prone to obsessions of this type. ${ }^{8}$

\section{Simons 11 .}

8. Simone de Beauvoir, The Prime of Life, trans. P. Green (Cleveland: World Publishing Company/Meridian Books, 1966) 178. Pilardi's 
Immediately after she adds that she might have decided to become a writer of secondary philosophical literature, a disciple in the sense in which Eugen Fink was a self-conscious disciple of Husserl's. She is confident that she would have been good at it, but she says she dismissed this option as a not especially interesting occupation, a career choice that she found puzzling. In the same breath, however, Beauvoir admits to having agreed to play this role "intermittently" in her later career-obviously with regard to Sartre, although Beauvoir does not name him. At this point the English translation adds the words "for various reasons." Instead of having her say, as she does in French, that later on it came about that she agreed to do so (il m' est arrivé de consentir), ${ }^{9}$ it reads that later she came to do it. To be sure, these are subtle deviations, but they prompted me to examine more carefully the passage cited by Pilardi in the French original.

Instead of addressing the silly or useless question as to why she herself did not become one of those rare creatures who are original philosophers, Beauvoir writes:

il faudrait plutôt expliquer comment certains individus sont capables de mener à bien ce délire concerté qu' est un système et d' où leur vient l'entêtement qui donne à leurs aperçus la valeur de clés universelles. J'ai dit déjà que la condition féminine ne dispose pas à ce genre d' obstination.

Once again there are subtle variations between the French original and the English translation; they interest me, and I hope they will be of general interest, for reasons that are not merely linguistic. First of all, the translation has it right when it has her say that such individuals "get results," mener à bien. But to translate "délire" as "lunacy" is a little strong; it is rather closer to the English "delirium,"

"Simone de Beauvoir Writing the Self" was first presented at a session of the Simone de Beauvoir Circle, Central Division, American Philosophical Association, in May 1999 in New Orleans. It is a synopsis of her book-length study, Simone de Beauvoir Writing the Self: Philosophy Becomes Autobiography (Westport: Greenwood Press, 1999).

9. Beauvoir, La Force de l' Âge (Paris: Gallimard, 1960) 229. The citation under consideration begins on page 228 . 
which is different from insanity. Also Beauvoir qualifies her expression with the adjective "concerte," which means deliberate or focused. The English text speaks of a "conscious venture into lunacy"--not quite, though almost, the same thing as "focused delirium." But the more dubious parts of this translation are to be found in the remainder of the sentence. First, "entêtement" clearly means "stubbornness" or "obstinacy," a point that is reinforced by Beauvoir's use of the word "obstination" at the end of the following sentence. In the English translation this becomes "obsession" with Freudian overtones that are entirely absent from the original. And whereas the formulation "tentative patterns" is not entirely unsuccessful at capturing "aperçus," which means something like "rough judgments," "universal insight and applicability" misses the original's philosophical significance by erasing the sarcasm and skepticism the phrase "la valeur de clés universelles" carries from an existentialist perspective even while appearing on the surface to reinforce the initial idea that such systems "get results." After all, for an existentialist of either the Sartrean or the Beauvoirean type values are created, not found in any imagined "nature of things." Hence, finally, for the English translation to render the words "la condition féminine" as "Women...by nature" is to do significant violence to the opening assertion of The Second Sex, to wit, that one is not a woman by nature ("One is not born a woman"), but rather becomes one.

The first thing to be said about this highly revealing passage is that it is a great example of a quality I have always admired in both Beauvoir and Sartre but that is more developed in Beauvoir: her enormous straightforwardness, her willingness to express exactly what she means without, as the unfortunate English metaphor has it, "pulling her punches." Of course, you need not agree with her, but you know exactly where she stands, at least on the literal level. This same text also shows her slightly bemused sense of self-doubt and of doubt about others-in this case the "great" systematic philosophers. How great were/are they really? She does not call them lunatics, but she does raise serious doubts about the truth-value of their entire enterprise, rare as that enterprise may be. She certainly implies disbelief in the idea that any one of them, Sartre included, has achieved or could ever achieve universal truth-even though they all, or at least many of them, have a value inasmuch as they offer some "universal keys" or clues. In a sense, doesn't she express satisfaction at her self-confessed incapacity to be like them? An heiress to the "feminine condition," she is not prone to "obstinacy" the way they, all male, are. Obstinacy usually is 
not considered an admirable quality, and the French "entêtement" she uses first has perhaps an even less positive connotation.

In sum, Beauvoir's language indicates that what these greats think they are doing when they give us a system is a self-delusion on their part. And this strikes me as something very "heavy." I see no way of characterizing her attitude toward Sartre here-as long as we take this passage at face value - as anything other than patronizing: the poor dear-brilliant but stubborn and deluded. Sartre, like the others before him, she suggests, is engaging in an impressive and potentially useful enterprise (as we all know, Beauvoir often employs technical, systematic terms from Sartre's philosophy, such as "in-itself", to illuminate ideas in her own writings), but ultimately it all constitutes a form of self-deception. By virtue of being a woman, even if she was not born one in the philosophically suspect sense, she claims to have been somewhat inoculated against this folly. Although I am not a woman, I have always shared Beauvoir's attitude about great philosophical systems; at the same time the perhaps typical American in me (as Simons and Benjamin would have it) questions her equation of such systems with philosophy as a whole. Having thus clarified Beauvoir's understanding of "philosophy" and her rationale for accepting the misleading dichotomy between philosophy and literature, let us now turn to the philosophical greatness of The Second Sex and the current renascence of interest in it.

\section{The Current Apotheosis of The Second Sex}

Recent books, articles, and symposia on Simone de Beauvoir as a philosopher have of course not taken The Second Sex as their sole focus. Among other works of special importance, one must first, as all would agree, consider her nearly contemporaneous Pour une Morale de l' Ambiguité, misleadingly translated as is so common with Beauvoir's titles (though not in the case of The Second Sex itself, where the mistranslations begin after the title page) as The Ethics of Ambiguity. Some scholars, notably Debra Bergoffen, ${ }^{10}$ find much value in Beauvoir's earlier ethical essay Pyrrhus et Cinéas despite the somewhat dismissive attitude Beauvoir herself took towards it in later years because of its excessively idealistic, optimistic tone. Kate Fullbrook

10. Debra Bergoffen, The Philosophy of Simone de Beauvoir: Gendered Phenomenologies, Erotic Generosities (Albany: SUNY Press, 1997). 
and Edward Fullbrook, whose strong anti-Sartre bias and resulting polemics have perhaps deflected attention from the strength and depth of their scholarship on Beauvoir, have paid special attention to her novel L' invitée (She Came to Stay), published in 1943 two months after Sartre's L' être et le néant, and present it as the source of a number of key concepts to be found in the latter. ${ }^{11}$ Beauvoir's other novels as well as her extensive autobiographical writings, letters, essays and, as I mentioned, her early diaries also have been mined for their philosophical significance. On the other hand, her major study of old age La vieillesse (The Coming of Age), which bears numerous, almost uncanny, resemblances to The Second Sex and certainly merits serious scholarly consideration has, to the best of my knowledge, undergone surprisingly little philosophical analysis.

But in the new scholarship on Beauvoir as a philosopher that characterizes the last half-decade or so, The Second Sex is most celebrated and analyzed the most and, I think, rightly so. What explains this proliferation? First there is the fact that 1999 marked the fiftieth anniversary of its original publication in Paris. Moreover, in the space of only a few years a number of the leading scholars of this renascence-Margaret Simons, Debra Bergoffen, Jo-Ann Pilardi, Kristana Arp, Sonia Kruks, Eleanore Holveck, Karin Vintges, and Eva Lundgren-Gothlin, among others-have either brought to completion their own original works or, in the case of the last two, supervised translations of their books into English. Special attention also needs to be paid, as it frequently is in informal settings but less often in print, to Margaret Simons' longstanding and tireless efforts to shame the members of the American Philosophical Association and especially the large Society for Phenomenology and Existential Philosophy into acknowledging the sexist bias that used to keep Beauvoir's name and work excluded from the philosophical canons they guarded. ${ }^{12}$ (Simons

11. Kate Fullbrook and Edward Fullbrook, Simone de Beauvoir and Jean-Paul Sartre: The Remaking of a Twentieth-Century Legend (London: Harvester Wheatsheaf, 1993).

12. See her "Sexism and the Philosophical Canon: On Reading Beauvoir's The Second Sex," in Journal of the History of Ideas LI (July 1990): 487-504; reprinted as Chapter 8 of Beauvoir and The Second Sex, 101-114. I discuss these efforts in more detail in "The Globalization of Philosophy," the final chapter of my book From 
must also be credited with spearheading an arrangement with Indiana University Press that will result in a series of scholarly editions of Beauvoir's work in English translation. It will include first-time translations of a number of essays and other writings, such as "Littérature et Métaphysique" and Pyrrhus et Cinéas, but probably no revised translation of The Second Sex, for which the current copyright holder long refused to waive its rights.)

No doubt, academic fads and vogues - those very concrete and powerful factors in the history of ideas about which most intellectuals as their bearers reflect only with some reluctance-are also at work. Many younger feminist theorists did not read The Second Sex in their formative years because in the circles in which they moved it was considered passé in many, if only vaguely articulated, respects: too pessimistic about women's future possibilities because rooted in the French scene of the 1940s, subservient to the philosophy of the despised Sartre (a claim that ironically echoes Beauvoir's most misogynist early critics), and above all, characterized by the type of grand narrative in the Hegelian tradition that postmodernism (according to the new grand narrative) had finally transcended. But the Alice in Wonderland world of intellectual faddism tends, among other things, to be somewhat pendulum-like. The exhaustion or at least waning of postmodernism has created space for reconsidering what preceded it. Early in 2000 in France, there was even a new Sartre fad, generated in part by the surprise publication of philosophical media celebrity Bernard-Henri Lévy's new major book on Sartre. It would be a distortion of fact to deny that the Beauvoir revival has received some of its impetus from similar factors. ${ }^{13}$

Yugoslav Praxis to Global Pathos: Anti-Hegemonic Post-Post-Marxist Essays (Lanham: Rowman \& Littlefield, 2002).

13. An excellent example of this, which also brings into play my previous candidate for explaining the renascence, is Scott Heller's article "Scholars Seek to Rank Simone de Beauvoir Among Leading $20^{\text {th }}$-Century Philosophers: Was the Author of 'The Second Sex' JeanPaul Sartre's Mouthpiece or His Muse?" in The Chronicle of Higher Education, September 4, 1998, pp. A22-A23. Taking as its point of departure a session on Beauvoir that was held during the quinquennial World Congress of Philosophy in Boston in August 1998, it includes photographs of Beauvoir herself and of Margaret Simons. More recently, just to close the media circle so to speak, Le Monde carried an 
Let me conclude, however, as a professional philosopher who likes to think that at least sometimes intellectual attention is brought to bear on certain works because of their intrinsic merit, by indicating just why The Second Sex ought to be considered a "breakthrough" work in philosophy. The Second Sex strikes me as paradigmatic with regard to bridging or overcoming the traditional philosophy-literature dichotomy. The heart of Beauvoir's method is to be found in Book 2, "Lived Experience." (Book 1 is a very interesting but more traditional admixture of philosophical criticism-critiques of biological, psychoanalytic, and Marxist determinisms--historical reconstruction, and literary analysis). There Beauvoir deploys a descriptive method that is clearly indebted to Husserl's but operates without the constraints of the strictest form of his epoche, or bracketing-out of existence claims, the possibility and validity of which already had been strongly and in my view convincingly challenged, especially by Maurice Merleau-Ponty, Beauvoir's colleague and acquaintance.

Within the traditions of modern Western philosophy, Sartre and Merleau-Ponty as post-Husserlian phenomenologists first elevated sexuality in different but not entirely incompatible ways to the status of a philosophically important category and gave it a significance that went much beyond the simpler, usually brief (and ultimately antifeminist) explorations of the social effects of gender inequality one finds in writers such as Locke, Rousseau, and Hegel. Sartre and Merleau-Ponty were also influenced by Freud, even if they strongly disagreed with various aspects of his theory-Merleau-Ponty with Freud's insistence that sexuality fundamentally shapes all human interaction, and Sartre with Freud's simplistic and rigid metaphysics, which tends to elevate concepts such as the super-ego and the unconscious to the status of allegedly real entities. But the terms both of these philosophical contemporaries of Beauvoir use to write about sexuality range from neuter or neutral (as if the question of sexuality could be dissociated from an individual's sexual identity) to clearly (but unavowedly) male-biased, and in the last analysis both remain

article about the annual two-day meetings of the Groupe d' Etudes Sartriennes in June 2000 in Paris that mentioned Lévy's appearance at the opening session but devoted more space to the special session on Beauvoir, at which Simons and Lundgren-Gothlin, among others, were speakers. (Jean Birnbaum, "Trois spectres chez les Sartriens," Le Monde, 30 juin 2000, p. XII.) 
complacent about the status quo in this domain of existence. ${ }^{14}$ Beauvoir's breakthrough consists in at once acknowledging and asserting the inescapable importance of the biological sexual differences between men and women, subtly showing on virtually every page how human society's collective interpretations of the practical implications of these differences (rather than, as in Freud, the mere male-female difference itself) permeate all facets of women's lives, and yet maintaining, over hundreds of pages, a fiercely critical stance toward past and contemporary practices on the basis of an unshakable conviction that the biological differences do not, logically speaking, lead to conservative, essentialist practical implications with respect to most aspects of everyday life. No writer before her, whether philosopher or author of fiction, had done this in such a sustained and systematic way, linking ontological issues about what is contingent and what is necessary in human existence with deft accounts of detailed experiences in the lives of concrete individuals, all from the standpoint of a committed social critic. Nor has anyone done so since.

So the prejudices that during the Carter and Reagan years and through the first Bush dynasty often prevented younger feminists from taking Beauvoir and The Second Sex more seriously than as an important historical milestone, no longer worth reading for its own sake, have gradually been recognized as, for the most part, mere prejudices. Is The Second Sex really pessimistic? Some of the sobering "data of biology" in the first chapter of Book 1 came from school

14. The chapter "The Body in its Sexual Being" in Merleau-Ponty's Phenomenology of Perception, trans. C. Smith (London \& New York: Routledge \& Kegan Paul, 1962) 154-173, is remarkable both for its strong insistence on the ambiguity of this phenomenon, so much in keeping with Beauvoir's overall philosophical perspective, and for its failure to explore the implications of sexual differences in any but the most superficial way. Sartre's bolder and better-known analysis of "Concrete Relations with Others" could be taken as neutral, since he uses the non-gender-specific pronoun "Autrui" to refer to the object of "my" sexual behaviors, but his English translator, Hazel Barnes, translates these passages as if this Other were female, because, she says, "The feminine sounds more natural in English": Being and Nothingness (New York: Philosophical Library, 1956) 390. It sounds that way, of course, because Sartre for the most part envisages these behaviors from a male standpoint. 
textbooks used during Beauvoir's adolescence. They were indeed fallacious and, as Margaret Simons showed in her Doctoral thesis, permeated with sexist presuppositions. But even these alleged data failed to curb Beauvoir's optimism about future possibilities. Anyone who completes reading both volumes of The Second Sex and imbibes in particular the spirit of the last two chapters, "The Independent Woman" and the "Conclusion," will agree with that. Does Beauvoir merely faithfully "apply" Sartre's or, for that matter, Merleau-Ponty's ideas to an area about which they had little or nothing to say? By no means. Nor does saying so deny or denigrate the intimate collaboration and intellectual cross-fertilization among the three of them. Tout compte fait, however, The Second Sex is profoundly original and creative. And finally, does the text present an account that falls under the now highly problematized category of "grand narrative"? Yes-if this is taken to include any work that employs theoretical generalizations, a criterion that would anathematize all works of theory. In fact, however, Beauvoir's approach in Book 2 of The Second Sex is paradigmatically "postmodern" in its insistence on the historical contingency and alterability of the phenomena of women's lived experience that it describes with such comprehensiveness, finesse, and style. Happily, some of the more repressive of these phenomena of life in late 1940s France since have disappeared through complex historical processes in which Beauvoir's ideas and example played a not insignificant role. But many other aspects - repressive or empowering-of women's lived experience that Beauvoir describes with such philosophical profundity and literary eloquence have not. The present intellectual celebration of The Second Sex is therefore thoroughly appropriate for our millennial time. 